cytological evolution. If inversions have a role in speciation in Drosophila, this role remains obscure and most likely is a minor one.

\section{ACKNOWLEDGMENTS}

Financial support for the work cited in this note was provided by the Natural Science and Engineering Research Council of Canada.

\section{Literature Cited}

Carson, H. L. 1975. Genetics of speciation. Amer. Natur. 109:83-92.

-. 1978. Speciation and sexual selection in Hawaiian Drosophila, p. 93-107. In P. F. Brussard (ed.), Ecological Genetics: The Interface. Springer-Verlag, N.Y.

Johnson, W. R., AND W. B. HeEd. Chromosomal polymorphism in the desert-adapted species Drosophila mojavensis. Evolution. In press.

MetTler, L. E. 1963. Drosophila mojavensis baja, a new form in the mulleri complex. Dros. Inf. Serv. 38:57.

WASSERMAN, M. 1962a. Cytological studies of the repleta group of the genus Drosophila III. The mercatorum subgroup. Texas Univ. Publ. 6205:63-71.

-. 1962b. Cytological studies of the repleta group of the genus Drosophila IV. The hydei subgroup. Texas Univ. Publ. 6205:73-83.

-1962c. Cytological studies of the repleta group of the genus Drosophila V. The mulleri subgroup. Texas Univ. Publ. 6205:85-117.

-1962d. Cytological studies of the repleta group of the genus Drosophila VI. The fasciola subgroup. Texas Univ. Publ. 6205:119-134.

- 1963. Cytology and phylogeny in Drosophila. Amer. Natur. 97:333-352.

Wharton, L. T. 1942. Analysis of the repleta group of Drosophila. Texas Univ. Publ. 9228:23-53.

White, M. J. D. 1978. Modes of Speciation. W. H. Freeman and Company, San Francisco.

Zouros, E. 1981a. The chromosomal basis of viability in interspecific hybrids between Drosophila arizonensis and Drosophila mojavensis. Can. J. Genet. Cytol. 23:65-72.

- 1981b. An autosome - Y chromosome combination that causes sterility in Drosophila mojavensis - Drosophila arizonensis hybrids. Dros. Inf. Serv. 97:703-718.

. 1981c. The chromosomal basis of sexual isolation in two sibling species of Drosophila: $D$. arizonensis and D. mojavensis. Genetics. In press.

Corresponding Editor: J. Patton

\title{
IS HOST CASTRATION AN EVOLUTIONARY STRATEGY OF BOT FLIES?
}

\author{
Robert M. Timm and Richard E. LeE, JR. \\ Division of Mammals, Field Museum of Natural History, Chicago, Illinois 60605 \\ and Department of Biology, University of Houston, Houston, Texas 77004
}

Received April 14, 1981. Revised July 5, 1981

In a review of host castration, Baudoin (1975) developed several hypotheses on why parasites, and bot flies (Diptera: Cuterebridae) in particular, should castrate their hosts. Many of his ideas on the strategy of host castration by parasites are appealing from an evolutionary point of view in that they incorporate increased fitness of the parasites. For example, castrated male hosts would provide the parasite with "a) increased energy availability, b) increased host viability and c) increased host growth" (Baudoin, 1975, p. 344).

However, Baudoin's basic assumption, that bot flies castrate their hosts, is erroneous.

Fitch (1857) was the first to suggest that bot flies castrated their hosts. He proposed the name "emasculator" for the chipmunk bot. In recent years, several papers have been cited repeatedly as providing evidence that castration does occur (i.e., Dalmat,
1942, 1943; Wecker, 1962; Dunaway et al., 1967; Getz, 1970; Hensley, 1976). None provide clear-cut evidence for host castration. A number of current parasitology, medical entomology, and veterinary texts contain blanket statements that bot flies emasculate their hosts (i.e., Chandler and Read, 1961; Krull, 1969; Cheng, 1973; Noble and Noble, 1976).

Seton (1920) did question whether host castration actually occurs, but unfortunately his paper has been largely ignored. Thus, the concept of host castration has been thoroughly entrenched in the literature in spite of the fact there is no supporting evidence.

Our work on Cuterebra emasculator parasitizing the eastern chipmunk, Tamias striatus, and $C$. fontinella parasitizing the white-footed mouse, Peromyscus leucopus, demonstrated that bot flies are found exclusively in the subcutaneous region between the skin and underlying muscle (Timm and 
Cook, 1979; Timm and Lee, 1981). They do not consume muscle or reproductive tissue, but rather feed on "tissue debris and exudate produced" (Payne and Cosgrove, 1966, p. 212). Generally, but not always, the site of larval development is in the posterior third of the host's body. It is usually found ventrally and the specific site is unrelated to the gonads. Bot flies are found on both male and female hosts in approximately equal numbers. Upon emergence of the mature larvae, the wound heals rapidly, with few apparent aftereffects. These observations on the life cycle of Cuterebra have been borne out by other investigators (Bennett, 1955; Payne et al., 1965; Dunaway et al., 1967).

Why is it that numerous workers have reported host castration by bot flies? First, a capsule that superficially resembles the testis is formed around a developing bot; this capsule may have been mistaken for a "consumed testis." On occasion, bot flies located in the scrotum may displace a testis anteriorly and/or dorsally; the larval bot then occupies the scrotal sac where the casual observer expects to find a testis (see photographs in Timm and Lee, 1981). And finally, bots located in the inguinal region of the female rodent create a pocket of swollen skin that superficially resembles a scrotum. Again, the casual observer removing the skin of the host would find bots where testicles were expected, although a more thorough examination within the body cavity would have revealed female reproductive organs.

Recent reviews by Kuris (1974) and Baudoin (1975) provide comprehensive treatment of host castration put into modern evolutionary context. Numerous cases of host castration by parasites have been documented; however, to date there are relatively few cases of vertebrate hosts being castrated and none as a result of parasitism by an arthropod (see Kuris, 1974; Moser and Taylor, 1978). Our work and a survey of the literature provides no evidence to substantiate host castration by bot flies. Bot fly parasitism may cause a temporary cessation of reproductive function, particularly in male hosts if the bot displaces the testis into the abdomen or if larvae mechanically prevent copulation. We must conclude, however, that parasitic castration is not an "evolved strategy" of bot flies.

\section{Literature Cited}

BAudoIn, M. 1975. Host castration as a parasitic strategy. Evolution 29:335-352.

BenNetT, G. F. 1955. Studies on Cuterebra emasculator Fitch 1856 (Diptera: Cuterebridae) and a discussion of the status of the genus Cephenemyia Ltr. 1818. Can. J. Zool. 33:75-98.

Chandler, A. C., AND C. P. ReAd. 1961. Introduction to Parasitology. John Wiley \& Sons, N.Y. 822 p.
Cheng, T. C. 1973. General Parasitology. Academic Press, N.Y. 965 p.

Dalmat, H. T. 1942. A new parasitic fly (Cuterebridae) from the northern white-footed mouse. J. N.Y. Entomol. Soc. 50:45-59.

-1943. A contribution to the knowledge of the rodent warble flies (Cuterebridae). J. Parasitol. 29:311-318.

Dunaway, P. B., J. A. Payne, L. L. Lewis, and J. D. StORY. 1967. Incidence and effects of $\mathrm{Cu}$ terebra in Peromyscus. J. Mamm. 48:38-51.

Fitch, A. 1857. Third report on the noxious and other insects of the state of New York. Trans. N.Y. State Agr. Soc. 16:315-490.

Getz, L. L. 1970. Botfly infestations in Microtus pennsylvanicus in southern Wisconsin. Amer. Midl. Nat. 84:187-197.

Hensley, M. S. 1976. Prevalence of cuterebrid parasitism among woodmice in Virginia. J. Wildl. Dis. 12:172-179.

KrUlL, W. H. 1969. Veterinary Parasitology. Univ. Kansas Press, Lawrence. 599 p.

KURIS, A. M. 1974. Trophic interactions: similarity of parasitic castrators to parasitoids. Quart. Rev. Biol. 49:129-148.

Moser, M., and S. Taylor. 1978. Effects of the copepod Cardiodectes medusaeus on the laternfish Stenobrachius leucopsarus with notes on hypercastration by the hydroid Hydrichthys sp. Can. J. Zool. 56:2372-2376.

Noble, E. R., ANd G. A. Noble. 1976. Parasitology: the Biology of Animal Parasites. Lea \& Febiger, Philadelphia. 566 p.

Payne, J. A., And G. E. Cosgrove. 1966. Tissue changes following Cuterebra infestation in rodents. Amer. Midl. Nat. 75:205-213.

Payne, J. A., P. B. Dunaway, G. D. Martin, And J. D. StoRy. 1965. Effects of Cuterebra angustifrons on plasma proteins of Peromyscus leucopus. J. Parasitol. 51:1004-1008.

Seton, E. T. 1920. Does the Cuterebra ever emasculate its host? J. Mamm. 1:94-95.

Timm, R. M., AND E. F. Cook. 1979. The effect of bot fly larvae on reproduction in white-footed mice, Peromyscus leucopus. Amer. Midl. Nat. 101:211-217.

Timm, R. M., AND R. E. Lee, JR. 1981. Do bot flies, Cuterebra (Diptera: Cuterebridae), emasculate their hosts? J. Med. Entomol. 18:333-336.

WECKER, S. C. 1962. The effects of bot fly parasitism on a local population of the white-footed mouse. Ecology 43:561-565.

Corresponding Editor: D. J. Futuyma 